\title{
Factors Influencing Levels of Corporate Social Responsibility Disclosure by Libyan Firms: A Mixed Study
}

\author{
Nagib Salem Bayoud \\ School of Accounting, Economics and Finance, Faculty of Business and Law \\ University of Southern Queensland (USQ), Australia \\ E-mail: NagibSalemBayoud@y7mail.com \& Nagib.Bayoud@usq.edu.au
}

Marie Kavanagh

School of Accounting, Economics and Finance, Faculty of Business and Law

University of Southern Queensland (USQ), Australia

E-mail: marie.kavanagh@usq.edu.au

Geoff Slaughter

School of Accounting, Economics and Finance, Faculty of Business and Law

University of Southern Queensland (USQ), Australia

E-mail: geoff.slaughter@usq.edu.au

Received: January 11, 2011

Accepted: February 20, $2012 \quad$ Published: April 1, 2012

doi:10.5539/ijef.v4n4p13

URL: http://dx.doi.org/10.5539/ijef.v4n4p13

\begin{abstract}
This paper explores whether company age, industry type and company size have a potential influence on levels of Corporate Social Responsibility Disclosure (CSRD) in the annual reports of Libyan companies. In this study quantitative and qualitative methods were used to collect data to determine the level CSRD in Libyan firms. Hypotheses are tested using regression analysis on a sample of 40 annual reports from Libyan companies' from 2007 to 2009. In addition, thirty one of the financial managers and information managers express their perceptions about the determinants of CSRD in Libya. The quantitative findings reveal that there is a positive relationship between company age and industry type and the level of CSRD. The qualitative findings show a positive relationship between all factors influencing levels of CSRD used in this study and level of CSRD in Libyan companies.
\end{abstract}

Keywords: Corporate Social Responsibility (CSR), Corporate Social Responsibility Disclosure (CSRD), Stakeholder theory, Annual report, Company Size, Company age, Industry type, Libya

\section{Introduction}

CSR refers to a company's voluntary contribution to sustainable development which goes beyond legal requirements (Gamerschlag et al., 2010). During the last 10 years, there has been a growing public awareness of the roles and responsibilities of corporations in society (Hackston \& Milne, 1996). While companies have been credited with contributing to economic and technological progress, they have also been criticised for creating social problems. Therefore, companies have started to engage in CSR activities and corresponding disclosure of these activities. At present, there are many large and older companies in particular that invest a great deal of effort and money to disclose information on their CSR performance. In this context, contribution and disclosure vary across industry sectors (Gray et al., 2001; Gray et al., 1995; Hackston \& Milne, 1996; McGuire et al., 2003; Waddock \& Graves, 1997). For example, companies in the oil sector are more focused on environmental issues, while companies in the food sector are involved more in community, health and food related CSR activities.

Previous studies on CSR, are characterised by three kinds of empirical research (Reverte, 2009). Firstly, there are'descriptive studies' which report on the extent and nature of CSR with some comparisons between countries and periods. Secondly, 'explicative studies,' focus on the potential factors influencing levels of CSR reporting. Thirdly, 
there are studies on the effect CSR information has on various users with an emphasis on market reaction. This study is explicative, as it analyses whether company size, company age and type of industry are potential factors influencing levels of CSRD practices by Libyan companies.

This paper is focused on the Libyan context for the following reasons. First, most of the present literature is based on the United States and the United Kingdom and thus evidence should be added about other contexts. Second, there are no known empirical studies on factors influencing CSRD by Libyan companies. Third, there are limited studies, which attempted to explore and explain these factors in developing countries. Finally, in contrast to the comprehension of CSR from common law developing countries, the factors influencing levels of CSR in Arabic countries are still relatively unknown. Therefore, the purpose of this paper is to explore whether company characteristics (company age, industry type and company size) have a potential influence on levels of CSRD practices on annual reports as disclosure media by Libyan firms.

The next section sets out the literature review, theoretical framework and development hypothesis about this topic. Section 3 describes the research methods used which includes quantitative and qualitative methods. Section 4 presents the findings and the final section sets out the conclusions.

\section{Literature Review}

Major corporate ethical disasters impacting on the environment, human resources, and the community have heightened the demand for public firms to voluntarily disclose their corporate social responsibility (CSR) activities to stakeholders. As a result, corporate social responsibility has become an important issue in the business world (Waller \& Lanis, 2009). In addition, CSRD is an extension of the financial disclosure system, which reflects the wider anticipation of society concerning the role of the business community in the economy. Furthermore, with the rapid collapse of cross-border economic barriers and the globalization of business, the role of CSR is being debated in an international arena (van der Laan Smith, Adhikari, \& Tondkar, 2005). The World Business Council for Sustainable Development (WBCSD) (1998, p. 3) defined CSR as: 'the continuing commitment by business to behave ethically and contribute to economic development while improving the quality of life of the workforce and their families as well as of the local community and society at large'. Also Mathews (1993) has defined social and environmental disclosure as: organisations voluntarily disclosing both quantitatively and qualitatively about their CSR activities in order to inform their stakeholders. Companies engage in CSR activities and its disclosure due to some motivations.

There are a number of motivational bases that explain the importance and benefits of company participation in CSR. These motivations are widely classified into strategic and altruistic (Lantos, 2001), positioning the economic motives and moral motives are considered as CSR involvement (Hillman \& Keim, 2001; Joyner \& Payne, 2002). Both scientific evidence (Margolis \& Walsh, 2003) and consumer reaction (McWilliams \& Siegel, 2001) have signalled to companies that engagement in CSR activities and its disclosure can be rewarded through improving company performance. In this regard, companies that engage in CSR activities and its disclosure can foster various stakeholder relations (McWilliams \& Siegel, 2001), thus reducing the company's business risk (Boutin-Dufresne \& Savaria, 2004). For these reasons, the strategic value of CSR is becoming increasingly recognized (Porter \& Kramer, 2002).

On the other hand, a range of company-level attributes can influence company CSR participation, and understanding these effects is essential, as companies try to derive strategic value from CSR. One of these effects, the issue of company size is identified as both relative and vital but as yet unexamined (Madden, Scaife, \& Crissman, 2006). Adams and Hardwick (1998) indicate that CSR activities and CSRD can be affected by company size that can affect strategic motivation i.e. strategic motivation can have a positive impact on CSR and CSRD. As larger companies tend to have a bigger CSR impact, given the scale of their activities (Cowen Linda \& Scott, 1987), larger companies are becoming increasingly aware of the importance and benefits of CSR and CSRD. Second, the issue of company age is also considered as an important factor that can affect levels of CSRD. Delaney and Huselid (1996) indicate that company age has a positive relationship with CSR and CSRD. Third, the issue of type of industry plays an important role in identifying the level of CSR activities and CSRD (McGuire, et al., 2003). For example, the level of CSR activities and CSRD differ from manufacturing sector to service sector (Kolk, 2003).

The majority of empirical studies on CSRD practices have focused on developed countries in particular the USA, the UK, Australia, Canada, Germany, Japan, New Zealand. Few studies have examined developing countries such as Malaysia, Singapore and Arabic countries (e.g. Libya, Egypt, Qatar and the UA). Most of the empirical studies into US practices have tended to employ the extensive survey evidence of Ernst and Ernst (1978), Guthrie and Parker (1990). Gray et al. $(1987,1995)$ provide survey evidence from the UK, with the later study including every year from 1979 to 1991. Surveys from Australia include Trotman (1979) and Guthrie (1983). Three surveys by Naser et 
al. (2006) and Mashat (2005) have provided some descriptions of CSRD in developing countries such as Libya and Qatar. This paper builds on previous research in developing countries by using content analysis of annual reports and personal interviews with managers to identify whether there are factors influencing levels of CSRD in Libya.

\section{Theoretical Framework}

CSRD has been the subject of substantial academic accounting research. Gray et al. (1987, p. 4) define CSRD:

...as the process of providing information designed to discharge social accountability. Typically this act would be undertaken by the accountable organisation and thus might include information in the annual report, special publications, or even socially oriented advertising.

To that effect, there are a number of theories that have been used to interpret why companies voluntarily disclose CSR information in their reports. In a review of accounting research, theory development related to CSRD in general is fragmented and rudimentary (Maali, Casson, \& Napier, 2006; Sadeghzadeh, 1995). The former effect is also identified with systems oriented theories such as legitimacy, agency theory, positive accounting, stakeholder and political economy theories (Deegan, 2002). In this context, the political and social contexts have been revealed to be major determinants of the decision to disclose CSR information (Roberts, 1992; Williams, 1999). While there are some similarities, the agency or positive accounting, legitimacy, and stakeholder theories essentially differ on the basis of fundamental assumptions. The agency or positive accounting theory makes the assumption of rational, wealth-maximizing individuals operating within the environment of efficient capital markets, while the stakeholder and legitimacy theories make no assumption of rationality. Woodward et al. (1996) have illustrated that a company is an important part of the wider social system in accordance with both stakeholder theory and legitimacy theory. Moreover, stakeholder theory suggests that some groups within the society are more powerful than others such as shareholders and employees, whereas legitimacy theory looks at society as a whole. The paper draws on Stakeholder theory and legitimacy theory to explain CSRD. Thus, the theoretical framework development here will incorporate both influences. The proposed model is presented in Figure 1 (see appendix 1).

Figure 1 explains the effects of company characteristics on CSRD using stakeholder theory. This model is based on the stakeholder's pressure in Libyan companies. First, stakeholders in large companies are more aware than small and medium companies about the importance of CSR activities for a company (H1:4). Large companies also tend to disclose more CSR information than small and medium companies. Moore (2001) and Branco and Rodrigues (2008), in particular, illustrated that amount of CSR disclosure in large companies is higher than smaller companies. Second, stakeholders in older companies have realized the role of CSR activities in improving a company's profits (H5:8). In addition, many studies found that the older companies provide more information about CSR activities than small companies. For instance, Delaney and Huselid (1996) revealed that company age has a major effect on levels of CSRD. Finally, the interests of stakeholders vary from industry to other (H9:12). Some sectors tend to disclose more information about some categories of CSRD than others. For instance, the oil sector is higher disclosure in environmental categories than others, while the manufacturing sector is more disclosed about community, safety and health related to CSR categories. Therefore, it can be seen that, company size, company age, and type of industry play an important role to affect levels of CSRD through the stakeholder's pressure.

\section{Development Hypotheses}

There are a number of empirical studies that have examined the link between CSRD and influences on levels of CSRD (Branco \& Rodrigues, 2008; Gray, et al., 1995; Murray, Sinclair, Power, \& Gray, 2006; Richardson \& Welker, 2001). The majority of these studies have found relations between CSRD and these factors (e.g. size, age, type of industry). The previous empirical studies relied on different theories (e.g. stakeholder theory, agency theory) to justify these relationships. Hence, in this paper, the researchers have used a multitheoretical framework in order to explain the differences in CSRD practices between listed firms. Next, the researchers discuss each of the explanatory factors used.

\subsection{Company Size}

Most empirical studies provide evidence that company size has an impact on the amount of CSRD (Branco \& Rodrigues, 2008; Gao, Heravi, \& Xiao, 2005; Gray \& Bebbington, 2001; Haniffa \& Cooke, 2005; Parsa \& Deng, 2008). These researchers found a significant and positive association between company size and amount of CSRD. The findings clarified the importance of this relationship. In addition, large companies tend to disclose more CSR information than small and medium companies. Moore (2001) and Branco and Rodrigues (2008) illustrated that the amount of CSRD in large companies is higher than small companies, because stakeholders expect greater CSRD from large companies than small companies. Large companies are also more able than small companies to communicate their CSR activities to external stakeholders (Rettab, Brik, \& Mellahi, 2009). Supporting that Cowen 
Linda and Scott (1987, p. 121) illustrate that "Corporate size appears to have significant impact" and argue that "social disclosure are correlated to company size for the reason that large companies have more stakeholders who might have concerns about the social activities undertaken by the company". Furthermore, large companies have more diverse ownership, and thus higher agency costs which management will attempt to reduce by disclosing more voluntary information (Meek, Roberts, \& Gray, 1995). Parsa and Deng (2008) indicate that a positive change in company size leads to positive and significant change in amount of CSR disclosure. However, some empirical studies found no relationship between size and amount of disclosure (Freedman \& Jaggi, 1988; Roberts, 1992). They found that large companies tend to report environmental information if they have weak economic performance. Hence, the discussion above leads to the hypotheses that:

H1: There is a positive significant relationship between company size and level of environmental disclosure.

$\mathrm{H} 2$ : There is a positive significant relationship between company size and level of consumer disclosure.

H3: There is a positive significant relationship between company size and level of community involvement disclosure.

H4: There is appositive significant relationship between company size and level of employee disclosure.

\subsection{Company Age}

A number of studies used company age as one of the most important factors that can affect level of disclosure, in particular CSRD (Delaney \& Huselid, 1996; Rettab, et al., 2009; Xianbing Liu \& Anbumozhi, 2009). Some studies revealed that there is a positive and significant relationship between level of CSRD and company age (Delaney \& Huselid, 1996). They think that the older companies provide more information about CSR activities than small companies. For instance, Delaney and Huselid (1996) found a positive link between CSR information and company age. However, some studies found that there is a negative association between the amount of CSRD and company age. For example, Rettab et al. (2009) revealed a negative relationship between CSR and company age, while Xianbing Liu and Anbumozhi (2009) found a negative relationship between environmental disclosure and company age. Hence, the discussion above leads to the hypotheses that:

H5: There is a positive significant relationship between company age and level of environmental disclosure.

H6: There is a positive significant relationship between company age and level of consumer disclosure.

H7: There is a positive significant relationship between company age and level of community involvement disclosure.

H8: There is appositive significant relationship between company age and level of employee disclosure.

\subsection{Type of Industry}

Level of disclosure and activities in CSR categories largely depends on type of industry in a company (Waddock \& Graves, 1997). For example, the manufacturing sector discloses more about community, safety and health related to CSR categories, while in the oil sector higher disclosure in environmental categories occurs. Therefore, type of industry plays an important role in determining amount of CSRD.

Several empirical studies have found a positive and significant relationship between CSRD and type of industry (Branco \& Rodrigues, 2008; Cowen Linda \& Scott, 1987; Gray, 2002; Newson \& Deegan, 2002; Parsa \& Deng, 2008; Wanderley, Lucian, Farache, \& de Sousa Filho, 2008). The previous results of empirical studies indicate that level and type of disclosure is significantly different, when companies are from different industries. This difference refers to stakeholder's pressure (D. Patten, 1991) and regulation imposed on some industries (Dierkes \& Preston, 1977). In addition to that, certain industries tend to disclose more CSR information due to their nature, and consumer-oriented firms are likely to exhibit more concern to demonstrate their social responsibility to their community, to enhance their image and increase profits (Cowen Linda \& Scott, 1987). Hence, the discussion above leads to the hypotheses that:

H9: There is a positive significant relationship between industry type and level of environmental disclosure.

H10: There is a positive significant relationship between industry type and level of consumer disclosure.

H11: There is a positive significant relationship between industry type and level of community involvement disclosure.

H12: There is appositive significant relationship between industry type and level of employee disclosure.

\section{Research Methods}

The paper employs quantitative and qualitative research methods to collect and analyse data using a triangulation approach (Jick, 1979). The use of purely quantitative methods in social science have been criticised because they are 
positivist and reductionist and therefore do not necessarily promote a good understanding of social constructs (Silverman, 2004). Quantitative methods are often treated as 'ad hoc procedures to define, count and analyse its variables' (Silverman, 2004, p. 13). It may not be adequate to obtain conclusive results by inferring that some directions of inquiry are meaningless because there are no statistically quantifiable answers (Patton, 1990). For instance, some outcomes inferred from statistical instruments alone may not be enough to explore and/or investigate some phenomena, nevertheless, these phenomena can often warrant further qualitative investigation (Hammersley, 1992). A purely positivist approach may thus exclude important information about the interrelationships between levels of CSRD and factors influencing of levels of CSRD. In this regard, the task of the social scientist is not only to gather facts and quantitatively measure how often certain patterns occur, but, also understand different constructs and interpret events with regard to the meanings people bring to them (Denzin \& Lincoln, 2000). Therefore, the use of qualitative methods by the researcher in this paper supports the quantitative methods, allows a deeper understanding, and results in data being more reliable and trustworthy. In order to support the interpretation between the two methods (Creswell 2009; Somekh \& Lewin 2005), mixed methods also enable the application of quantitative results to support the interpretation of qualitative results (Creswell 2009). Finally, mixed methods builds strong outcomes and avoid social bias (Gorard \& Taylor, 2004; Johnson \& Onwuegbuzie, 2004; Kreuger \& Neuman, 2006).

\subsection{Sample and Data Collection}

The sample represents four different sectors. These sectors include (based on the classification presented by the Libyan Public Control Office) Manufacturing companies, service companies, banks and insurance companies, and mining companies. The four sectors were chosen in this paper, because they are considered the most important sectors in Libya (Mashat, 2005). The sample (population) for the current paper included 135 Libyan organisations across the four sectors. The sample encompassed 32 manufacturing companies, 8 mining companies, 20 banking and insurance companies, and 75 services companies.

For the quantitative analysis a three-year period from 2007 to 2009 was chosen for this paper. A final sample of 40 firms was collected [see tables 1 (appendix 2) and 2 (appendix 3)]. Annual reports were obtained for each of the years in a three year period from 40 companies. To overcome the barriers of secrecy in Libya which might affect the response rate, an approach similar to that of snowball sampling was adopted. The annual reports of this paper were collected through using the company web pages and/or by visiting the company office. Personal relationships were utilized to find contacts who could obtain the required annual reports. This means that the 40 companies included in the study $12(37.5 \%)$ were manufacturing companies, 1 mining company, 13 banking and insurance companies, and 14 were services companies [see table 1 (appendix 2)]. This paper also employed content analysis as a systematic method of categorising and analysing the content of texts. Company characteristics and levels of CSRD were collected from annual reports by using content analysis method.

For the qualitative analysis, the paper gathered information using face to face semi-structured interviews with key internal stakeholders such as financial managers and information managers. In addition, knowledge gathered from consulting with other researchers in CSRD and literature reviews enabled the researchers to design an interview guide with common questions to ask the interviewees [see table 3 (appendix 4)].

This paper consists of the above mentioned 40 firms which data were collected from in the quantitative stage. Thirty one managers were interviewed to gain insights into their perceptions about the effect of company size, company age and type of industry on levels of CSRD. Data gathered from interviews with financial managers and information managers was recorded by a note and tape recorders to enable the researchers to gain deeper insights for the purpose of this research. The interviews took place between October 2010 and February 2011. The meetings were held in the manager's office.

\subsection{Empirical Models}

A number of empirical studies have used quantitative method which included statistical techniques to examine the relationship between levels of CSRD and factors influencing of levels of CSRD (Branco \& Rodrigues, 2008; Gamerschlag, et al., 2010; Gray, Javad, Power, \& Sinclair, 2001; Hackston \& Milne, 1996; Reverte, 2009). The Reverte's study (2009) used the statistical analysis technique which included the use of linear regression models by Spanish Listed Firms to analyse the relationship between CSRD and each of the influencing factors of CSRD such as company size, industry sensitivity, profitability, concentrated ownership, international listing, media exposure, and leverage. The statistical analysis technique was also employed by Gamerschlag et al. (2010) to identify determinants of voluntary CSR disclosure in German firms. Company visibility, profitability, shareholder structure and relationship with stakeholders were utilized in the linear regression models as the influencing factors of CSRD in German firms. In addition, the Branco and Rodrigues study (2008) used linear regression to investigate whether 
there is an association between international experience, company size, industry affiliation, environmental sensitivity and media exposure with CSRD in Portuguese Companies. The statistical analysis techniques which includes a linear regression is adapted to exmine the relationship between the factors in this study and levels of CSRD.

The purpose of multivariate regression was used to measure, explain and predict the degree of linkage among variables (Hair, Black, Babin, \& Black, 2006). Therefore, this paper used the following regression models through SPSS program to examine the relationship between factors influencing levels of CSRD and CSRD as being proposed by the following multivariate regressions.

$$
\begin{gathered}
\mathrm{ENVD}=\alpha+\beta_{1} \mathrm{SIZE}+\beta_{2} \mathrm{AGE}+\beta_{3} \mathrm{INDTY}+\varepsilon \\
\mathrm{COND}=\alpha+\beta_{1} \mathrm{SIZE}+\beta_{2} \mathrm{AGE}+\beta_{3} \mathrm{INDTY}+\varepsilon \\
\mathrm{COMD}=\alpha+\beta_{1} \mathrm{SIZE}+\beta_{2} \mathrm{AGE}+\beta_{3} \mathrm{INDTY}+\varepsilon \\
\mathrm{EMPD}=\alpha+\beta_{1} \mathrm{SIZE}+\beta_{2} \mathrm{AGE}+\beta_{3} \mathrm{INDTY}+\varepsilon
\end{gathered}
$$

Where CSRD represents the dependent variables (Environment (ENVD), Consumers (COND), Community involvement (COMD) and Employee (EMPD)), SIZE refers to the Size of the firm that was measured by the number of years since establishment in Libya as independent variable (Rettab, et al., 2009), AGE refers to the Age of the firm that was measured by total of assets as independent variable (Branco \& Rodrigues, 2008), INDTY refers to the Industry type that was measured by a dummy variable that takes the value of " 1 " if a firm is in a manufacturing and mining sector, and the value of "0" if otherwise as independent variable (Elsayed \& Hoque, 2010), and B is the coefficient of the independent variables.

\subsection{Interview Analysis}

Miles and Huberman (1994) approach was used to analyse the qualitative data. CSR activities were classified into four categories (employee commitment, community involvement, consumer and product and environment). Analysis of the qualitative data employed two stages. First, the researcher classified the interview content (transcript) into similar or different responses. Second, key, substantive points were identified and put into categories (Gillham, 2000). Identifying a code was the first analysis process with each transcript. Then all the transcripts were read more than one time by the researcher. At the same time, substantive statements related to the research focus were highlighted (Gillham, 2000; Marshall \& Rossman, 1999). After a review of all the transcripts, tape recordings were reviewed in order to find any intonations and statements that required highlighting (Kamla, 2007). Statements from interviews were drawn from this stage, which involved further composition. Highlighted statements were allocated simple headings through derivation of a set of categories for the responses to each question (Gillham, 2000). These categories and headings were checked against the highlighted statements and any necessary amendments were made. The researcher repeated this procedure more twice to ensure that no categories and headings were missed (Hanafi, 2006). A matrix was prepared by analysing the transcripts and assigning each highlighted statements to a category (Gillham, 2000). In addition, the researcher maintained a second separate file to record the overall observations to enhance the meaning of the data for all interviews.

\section{Results}

\subsection{Content Analysis of Annual Reports}

This paper employed content analysis as a systematic method of categorising and analysing the content of texts. The form of content analysis analyses the CSRD of each category using a "yes/no" or $(1,0)$ scoring methodology. If there is information of subcategories (items), these subcategories will gain a score of 1 , whereas a score of 0 will be awarded if no information subcategory is disclosed .The aggregate score for each company is determined by adding up scores of 1 (Al-Tuwaijri, Christensen, \& Hughes, 2004). Finally, the final disclosure score indexes for each category are calculated using the following formula:

$$
X I=\sum_{\tau=1}^{\mathrm{mj}} \frac{\mathrm{X} \tau}{N}
$$

This index indicates the level of CSR disclosure for a firm $\mathrm{j}$, where $\mathrm{N}$ is the maximum number of relevant subcategories a firm may disclose and $X \tau$ is equal to 1 if disclosed or 0 if not (Branco and Rodrigues, 2008).

In the case of the manufacturing sector, environmental disclosure total was 32 of 84 scores; for consumer disclosure total was 19 of 48 scores; for community disclosure was 5 of 60 scores; and for employee disclosure was 43 of 108 scores (CSRD total was 99 of 300 scores). In the case of mining sector, environmental disclosure was 7 of 7; for 
consumer disclosure was 1 of 4 scores; for community disclosure was 1 of 5 scores; and for employee disclosure was 4 of 9 scores (CSRD total was 13 of 25 scores).

CSR information disclosed in the annual reports in both tables 3 (see appendix 5) indicates that consumer information and employee information are high compared with community information and environmental information which are low in the four sectors. The consumer category are in two subcategories (product and consumer safety (74.54\%) and provision for difficult to reach consumers $(24.54 \%)$, followed by consumer complaints $(20.90 \%)$ and provision for disabled $(2.72 \%)$, whereas employee others such as benefits presented to employees during the time work $(86.36 \%)$, employee data $(75.54)$, health and safety $(42.72 \%)$ and pension data (31.81\%) are subcategories with a high visibility in employee information.

The results of Mashat's study (2005) and Elmogla's study (2009) are similar to the results of table 3 (see appendix 5). For instance, employee information disclosed represents a significant part of the CSRD made by companies in these sectors, while community information receives the lowest disclosure in these sectors.

\subsection{Quantitative Results}

\subsubsection{Descriptive Analysis}

Table 4 (see appendix 6) presents descriptive statistics for all the variables of interest. The average indexes illustrate higher disclosure on consumer information (mean $=0.382$ ), employee information (mean $=0.358)$, and community information (mean $=0.255)$ and less disclosure on environmental information (mean $=0.216)$. The maximum and minimum values of consumer information are 0 and 1 , the values of employee information are 0.11 and 0.56 , the values of community information are 0 and 0.80 , and the values of environmental information are 0 and 1 respectively.

The data showed in Table 4 (see appendix 6) illustrates the perceived effect of company size on levels of CSRD can be ranked as (1), followed by the perceived effect of company age on levels of CSRD (21.70), whereas type of industry (0.33) can be ranked as (3). The maximum and minimum values of size are 5543094 and 17287053953 , ages are 1 and 52 years, and types of industry are 0 and 1 respectively.

The descriptive statistics (skewness and kurtosis) for the dependent, independent and control variables showed in Table 4 indicate that the overall disclosure index and all dependent variables are normally distributed (both skewness and kurtosis coefficients are not significantly different from zero at the 0.05 level of significance).

\subsubsection{Correlation Analysis}

The Pearson and Spearman's Rho Correlation coefficients for the association between some company characteristics and level of CSRD in under four categories are reported in Table 5 (see appendix 7).

Table 5 (see appendix 7) presents a preliminary indication that some independent variables are associated with levels of CSRD indexes. The correlations are significant and positive between some independent variables and the CSRD indexes. The perceived influence of type of industry results in higher correlations with environmental disclosure $(0.519$ and 0.545 , p-value $<0.01)$ than the majority of independent variables. In addition, the perceived influences of company size and company age have higher correlations with consumer disclosure $(0.392$, p-value $<$ $0.05)$ and $(0.429$ and $0.468, \mathrm{p}$-value $<0.01)$. These results mean that they are significantly positively correlated indicating that in this sample, as company size and company age increase, level of environmental disclosure also increases. Furthermore, At the significant level of $1 \%$ and $5 \%$, there is a positive correlation coefficient of $(0.355$, $0.439)$ and $(0.443,0.465)$ respectively between company size and company age with employee disclosure, which indicate that an increase in company size and company age leads to an increase in the amount of employee disclosure. As can be seen from Table 5 (see appendix 7), two dependent variables have more than one correlation with independent variables. However, only community disclosure has not significantly correlated with company size, company age and type of industry indexes. The results pertaining to correlations between dependent variables and independent variables in both Pearson correlation and Spearman's Rho correlation tables are relatively similar.

\subsubsection{Multivariate Regression Analysis}

Tables 5 (see appendix 7) and 8 (see appendix 10) are utilized to check multicollinearity. If the coefficients of correlation between continuous independent variables exceed 0.800 , that is indicative of serious Collinearity (Guajarati, 1995). Table 5 (see appendix 7) shows that the correlations between the continuous independent variables are low, indicating no serious multicollinearity. In addition, Table 8 Collinearity statistics illustrate that there is no problem with multicollinearity, because the highest variance inflation factor (VIF) in the regressions are less than 3. Kennedy (1992) considers that based on the VIF, multicollinearity is a serious problem if continuous independent variables exceeds 10 . In Table 8 data are also checked for homoscedasticity and linearity. 
A residuals analysis is applied to the results, the problem of linearity and heteroscedasticity does not exist in the data. (Noruésis, 1995, p. 447) defined Residuals as 'what are left over after the model is fit and they are also the difference between the observed value of the dependent variable and the value predicted by the regression line'.

The Durbin-Watson (DW) is utilized to test the independent errors (autocorrelation), at a level of significance of 0.05. The result of the Durbin-Watson $d$ value can be a range from 0 - 4. If $d$ value of the Durbin-Watson equals 2, this leads to the independent error. For accuracy, the Durbin-Watson d value that is greater than 3 or less than 1 is definitely reason for concern (Field, 2009). The Durbin-Watson d values in these data are between 1 and 2 and they are not greater than 3 or less than 1 . Therefore, autocorrelation does not present a problem with the data.

Multivariate regression models are applied to test the relationship between company characteristics in terms of company size, company age and type of industry, and levels of CSRD in annual reports of the years for 2007-2009 using the four sectors in the next paragraphs.

With regard to the regression models, the regression results of these models are given in Tables 6,7 and 8 (see appendix 8, 9 and 10) respectively. Social scientists use a cut of point of 0.05 as their criterion for statistical significance. Hence, because the observed significance value is less than 0.05 the results indicate that there was a significant impact of some factors influencing levels of CSRD on levels of CSRD, these values are between equal 0.004 and 0.031 shown in table 7 (see appendix 9). However, the results of the regression model 3 illustrated no significant effect of factors influencing levels of CSRD on the levels of CSRD, this value are 0.329 shown in table 7 (see appendix 9). This means that the relationship between company size, company age, and type of industry with levels of CSRD is to some extent positive which affirms the hypotheses drawn. Additionally, it indicates that, as long as company size, company age and type of industry increase environmental disclosure, consumer disclosure and employee disclosure thus will increase, this emphasis the theoretical view of stakeholder theory. The following two tables 6 and 7 (see appendix 8 and 9) show the descriptive results of the Model Summary and the regression models.

Although the data in table 8 (see appendix 10) do not find a significant and positive relationship between company size and levels of CSRD, and the three factors and employee disclosure, the coefficients drawn in table 8 (see appendix 10) suggest that the independent variable is associated with the dependent variable. Accordingly, it is shown that as company age increases, levels of environmental and consumer disclosure also increase. This means that company age is positively associated with levels of CSRD, and type of industry is a significant and positively associated with levels of environmental disclosure.

\subsection{Qualitative Results}

The accounting literature review showed a number of studies which revealed the link between company size, company age and type of industry and levels of CSR information disclosed (see the literature review section). The literature review illustrated that there is a strong association between these factors and the amount of CSR information disclosed. Therefore, the following question was asked of all interviewees:

Does the size, age of your organization, and industry type affect the level of CSR information provided by your organization, If yes, how?

The results of interviews for this question are shown in table 9 (see appendix 11) below.

Table 9 (see appendix 11) shows the opinion of financial managers and information managers about the relationship between CSR information disclosed and some factors such as company size, company age and type of industry. Most interviewees believe that level of CSR information in annual reports can be influenced by age of the company as it enabled the companies to obtain expertise and competence sufficient for improving the preparation of all information.

Longevity of the business gives the company expertise and adequate competence to improve the preparation of information through the annual report from market needs for this information and its impact on company performance.

Most interviewees mentioned that large companies disclosed more CSR information than smaller companies due to difference of companies' activities and size. Furthermore, they stated that stakeholders in the large companies can influence the management of these companies for disclosing CSR information compared with others. Moreover, they believe that the management of large companies realized the importance of CSRD more than small companies as illustrated in the following comments:

I think that the large companies have the highest level of social disclosure due to them realizing the importance of social activities and most decisions are based on this information... more services and more social and 
environmental information... the volume of dealings and the multiplicity of stakeholders need to provide a variety of information and much information to meet the requirement of stakeholders... and its impact on stakeholders is reflected on the company's performance in the market.

Size does not only affect in terms of the commitment of the company but it affects volume of information and this is due to the administration being convinced of the importance of dissemination of this information in order to benefit from disclosure.

The financial managers and information managers mentioned a significant effect of type of industry on level of CSR information in annual reports. The majority of interviewees believe that level of CSR information in annual reports differs from one sector to another due to variation of activity type:

I believe, type of industry has a major impact on the amount of social information disclosed, particularly with regard to industrial companies because the company possesses and exposes all kinds of CSR information.

However, one of the financial managers believes that the policy of management about the importance of disclosing CSR information plays an important role in increasing the amount of CSR information in their annual reports:

Yes, In addition to these elements, the policy of senior management and its orientation towards social disclosure significantly affects the quantity and quality of information disclosed in annual reports.

One of financial managers stated that private companies that are listed in the stock market give more details about CSR information disclosed than public companies, because the private companies seek to meet the requirements of a bigger number of stakeholders through disclosing all information in their annual reports:

Yes, but the private companies that possess shares in the stock market and the bigger number of stakeholders have a higher level of disclosure than the public companies regardless size, age and type of industry.

To sum up, the findings of the interviews support the research. First of all, the findings reveal that company size, company age and type of industry can affect a level of CSRD in Libyan companies. Second, there is a positive relationship between these factors and a level of CSRD. Finally, these findings also support some quantitative results in this study.

\section{Conclusion}

This paper provided an analysis of whether company size and company age, as well as type of industry, are potential determinants of CSRD practices by Libyan companies. Empirical studies have shown that CSR activities and CSRD varies across companies due to the difference of size, age and industries (Gray et al. 1995; Hackston \& Milne 1996). They have also shown that this activity and its disclosure are important and systematically determined by company characteristics that affect the relative levels of CSR information disclosure and its performance (Cormier et al. 2005; Hackston \& Milne 1996; Patten 2002; Reverte 2009).

The quantitative findings of this paper present evidence that older companies have higher levels of CSRD in terms of environmental disclosure and consumer disclosures compared with companies with lower levels of CSRD. In addition, higher levels of CSRD belong to more environmentally sensitive industries (such as manufacturing sectors) compared with insensitive industries. However, neither company age and nor type of industry seem to explain differences in community disclosure and employee disclosure practices in Libyan companies.

Furthermore, levels of CSRD do not seem to be affected by company size in Libyan companies. The most influential variable for explaining companies' variation in levels of CSRD is company age, followed by industry type. In contrast with the quantitative findings in this paper, the qualitative findings indicated a stronger effect of company size, company age and type of industry on levels of CSRD. According to the qualitative findings, company size, company age and type of industry can explain differences in levels of CSRD in Libyan companies. Therefore, it appears that the results of this paper align with stakeholder theory, as captured by those variables related to social visibility in terms of stakeholders' interests as the most relevant theory for explaining CSRD practices of Libyan companies. Thus, Libyan companies report on CSR activities mainly to act and be seen to be acting within the bounds of what is considered acceptable according to the expectations of stakeholders about how their operations should be conducted.

This paper provides three main contributions to CSRD research: first, it presents the first empirical data related to Libyan companies and adds to the previous research on CSRD; second, it extends previous research that links company characteristics with level of CSRD using stakeholder theory. Third, it reveals the nature of the relationship between company characteristics and level of CSRD and is important to encouraging firms to improve CSR data in their annual reports in Libya. 
However, this paper has a number of limitations: first, this paper focuses only on CSRD in annual reports, although these companies use other mass communication mechanisms. Second, although it consists of most of the relevant Libyan companies, this sample is likely to be considered small; hence the use of a larger sample by Libyan companies are likely to add new insights to analyse of CSRD. Finally, it is probable that content analysis issues might contribute to the level of subjectivity in the coding process.

There are several directions for future research that flow from this paper. First, the quantitative study of this paper used a range of data analysis techniques to identify findings including linear regression. Future research should use nonlinear regression. This phase used some independent variables such as company size, company age and industry type on a small and less diverse sample, therefore future research would require adding / using other variables such as profitability, culture and regulations on a larger and more diverse sample. In addition, because content analysis is associated with the level of subjectivity involved in the coding process, future research should use more refined content analysis methods, analyses of the categories of CSRD taken individually, and the use of larger samples of companies.

The qualitative study in this paper collected data from internal stakeholders such as financial managers and information managers. Future research should use external stakeholders or both of them to understand the effect of company characteristics on level of CSRD. It can also compare perceptions of internal stakeholders and external stakeholders to comprehend the link between company characteristics and CSRD.

In conclusion, the results of this paper suggest that company size, company age and type of industry that affect CSRD practices of Libyan companies are not significantly different from companies in developed countries which are affected by similar factors influencing levels of CSRD. This confirms the results of Cormier and Magnan (2003), who suggest that disclosure strategies are determined, regardless of a given country's socio-cultural context.

\section{References}

Adams, M., \& Hardwick, P. (1998). An analysis of corporate donations: United Kingdom evidence. Journal of management Studies, 35, 641-654. http://dx.doi.org/10.1111/1467-6486.00113

Al-Tuwaijri, S. A., Christensen, T. E., \& Hughes, K. E. (2004). The relations among environmental disclosure, environmental performance, and economic performance: a simultaneous equations approach. Accounting, Organizations and Society, 29, 447-471. http://dx.doi.org/10.1016/S0361-3682(03)00032-1

Boutin-Dufresne, F., \& Savaria, P. (2004). Corporate social responsibility and financial risk. The Journal of Investing, 13, 57-66. http://dx.doi.org/10.3905/joi.2004.391042

Branco, M. C., \& Rodrigues, L. L. (2008). Factors influencing social responsibility disclosure by Portuguese companies. Journal of Business Ethics, 83, 685-701. http://dx.doi.org/10.1007/s10551-007-9658-z

Cormier, D., \& Magnan, M. (2003). Environmental reporting management: a continental European perspective. Journal of Accounting and Public Policy, 22, 43-62. http://dx.doi.org/10.1016/S0278-4254(02)00085-6

Cormier, D., Magnan, M., \& Van Velthoven, B. (2005). Environmental disclosure quality in large German companies: economic incentives, public pressures or institutional conditions? European Accounting Review, 14, 3-39. http://dx.doi.org/10.1080/0963818042000339617

Cowen Linda, B., \& Scott, S. (1987). The impact of corporate characteristics on social responsibility disclosure: a typology and frequency-based analysis. Accounting, Organizations and Society, 12, 111-122. http://dx.doi.org/10.1016/0361-3682(87)90001-8

Creswell, J. W. (2009). Research design: Qualitative, quantitative, and mixed methods approaches. 2nd ed, Los Angeles: Sage Publications, Inc.

Deegan, C. (2002). The legitimising effect of social and environmental disclosures-a theoretical foundation. Accounting, Auditing \& Accountability Journal, 15, 282-311. http://dx.doi.org/10.1108/09513570210435852

Delaney, J. T., \& Huselid, M. A. (1996). The impact of human resource management practices on perceptions of organizational performance. Academy of Management Journal, 39, 949-969. http://dx.doi.org/10.2307/256718

Denzin, N. K., \& Lincoln, Y. S. (2000). The discipline and practice of qualitative research. Handbook of qualitative research, 2, 1-28.

Dierkes, M., \& Preston, L. E. (1977). Corporate social accounting reporting for the physical environment: a critical review and implementation proposal. Accounting, Organizations and Society, 2, 3-22. http://dx.doi.org/10.1016/0361-3682(77)90003-4 
Elmogla, M. (2009). Corporate Social Reporting in a Transition Economy: The Case of Libya. University of Huddersfield, Huddersfield, UK.

Elsayed, M. O., \& Hoque, Z. (2010). Perceived international environmental factors and corporate voluntary disclosure practices: An empirical study. The British Accounting Review, 42, 17-35. http://dx.doi.org/10.1016/j.bar.2010.01.001

Ernst, \& Ernst. (1978). Social Responsibility Disclosure, 1978 Survey. Cleveland, OH: Ernst \& Ernst.

Field, A. P. (2009). Discovering statistics using SPSS. London: SAGE publications Ltd.

Freedman, M., \& Jaggi, B. (1988). An analysis of the association between pollution disclosure and economic performance. Accounting, Auditing \& Accountability Journal, 1, 43-58. http://dx.doi.org/10.1108/EUM0000000004623

Gamerschlag, R., Möller, K., \& Verbeeten, F. (2010). Determinants of voluntary CSR disclosure: empirical evidence from Germany. Review of Managerial Science, 1-30.

Gao, S. S., Heravi, S., \& Xiao, J. Z. (2005). Determinants of corporate social and environmental reporting in Hong Kong: a research note. Account Forum, 29, 233-242. http://dx.doi.org/10.1016/j.accfor.2005.01.002

Gillham, B. (2000). The Research Interview. London: Continuum.

Gorard, S., \& Taylor, C. (2004). Combining methods in educational and social research. London:Open Univ Press.

Gray, R. (2002). The social accounting project and accounting organizations and society privileging engagement, imaginings, new accountings and pragmatism over critique? Accounting, Organizations and Society, 27, 687-708. http://dx.doi.org/10.1016/S0361-3682(00)00003-9

Gray, R., \& Bebbington, J. (2001). Accounting for the Environment. London: Sage Publications.

Gray, R., Javad, M., Power, D. M., \& Sinclair, C. (2001). Social and Environmental Disclosure and Corporate Characteristics: A Research Note and Extension. Journal of Business Finance \& Accounting, 28, 327-356.

Gray, R., Kouhy, R., \& Lavers, S. (1995). Corporate social and environmental reporting. Accounting, Auditing \& Accountability Journal, 8, 47-77. http://dx.doi.org/10.1108/09513579510146996

Gray, R., Owen, D., \& Maunders, K. (1987). Corporate Social Reporting: Accounting and Accountability. London: Prentice Hall.

Guajarati, D. N. (1995). Basic econometrics. New York: McGrawHill.

Guthrie, J. (1983). Corporate social accounting and reporting: an Australian empirical study. Paper presented at the unpublished paper, AAANZ Conference, Brisbane.

Guthrie, J., \& Parker, L. D. (1990). Corporate social disclosure practice: a comparative international analysis. Advances in Public Interest Accounting, 3, 159-176.

Hackston, D., \& Milne, M. J. (1996). Some determinants of social and environmental disclosures in New Zealand companies. Accounting, Auditing \& Accountability Journal, 9, 77-108. http://dx.doi.org/10.1108/09513579610109987

Hair, J. F., Black, W. C., Babin, B. J., \& Black, W. C. (2006). Multivariate Data Analysis. 6th ed. New Jersey: Prentice Hall.

Hammersley, M. (1992). 'Deconstructing the Qualitative-Quantitative Divide', in J. Brannen (ed.), Mixing Methods: Qualitative and Quantitative Research, Aldershot, UK : Avebury.

Hanafi, R. A. (2006). An exploration of corporate social and environmental disclosure in Egypt and the UK: a comparative study, Cornwall, University of Exeter, UK.

Haniffa, R. M., \& Cooke, T. E. (2005). The impact of culture and governance on corporate social reporting. Journal of Accounting and Public Policy, 24, 391-430. http://dx.doi.org/10.1016/j.jaccpubpol.2005.06.001

Hillman, A. J., \& Keim, G. D. (2001). Shareholder value, stakeholder management, and social issues: what's the bottom line? Strategic Management Journal, $22, \quad$ 125-139. http://dx.doi.org/10.1002/1097-0266(200101)22:2<125::AID-SMJ150>3.0.CO;2-H

Jick, T. D. (1979). Mixing qualitative and quantitative methods: Triangulation in action. Administrative Science Quarterly, 24, 602-611. 
Johnson, R. B., \& Onwuegbuzie, A. J. (2004). Mixed methods research: A research paradigm whose time has come. Educational Researcher, 33, 1-14. http://dx.doi.org/10.2307/2392366

Joyner, B. E., \& Payne, D. (2002). Evolution and implementation: a study of values, business ethics and corporate social responsibility. Journal of Business Ethics, 41, 297-311. http://dx.doi.org/10.1023/A:1021237420663

Kamla, R. (2007). Critically appreciating social accounting and reporting in the Arab Middle East: a postcolonial perspective. Advances in International Accounting, 20, 105-177. http://dx.doi.org/10.1016/S0897-3660(07)20005-4

Kennedy, P. (1992). A guide to econometric methods. Cambridge. MA: MIT Press.

Kolk, A. (2003). Trends in sustainability reporting by the Fortune Global 250. Business strategy and the environment, 12, 279-291. http://dx.doi.org/10.1002/bse.370

Kreuger, L. W., \& Neuman, W. L. (2006). Social work research methods: Qualitative and quantitative applications. Boston, MA: Allyn and Bacon.

Lantos, G. P. (2001). The boundaries of strategic corporate social responsibility. Journal of consumer marketing, 18, 595-632. http://dx.doi.org/10.1108/07363760110410281

Maali, B., Casson, P., \& Napier, C. (2006). Social reporting by Islamic banks. Abacus, 42, 266-289. http://dx.doi.org/10.1111/j.1467-6281.2006.00200.x

Madden, K., Scaife, W., \& Crissman, K. (2006). How and why small to medium size enterprises (SMEs) engage with their communities: an Australian study. International Journal of Nonprofit and Voluntary Sector Marketing, 11, 49-60. http://dx.doi.org/10.1002/nvsm.40

Margolis, J. D., \& Walsh, J. P. (2003). Misery loves companies: Rethinking social initiatives by business. Administrative Science Quarterly, 48, 268-305. http://dx.doi.org/10.2307/3556659

Marshall, C., \& Rossman, G. (1999). Designing Qualitative research. London: Sage Publications Ltd

Mashat, A. A. (2005). Corporate Social Responsibility Disclosure and Accountability (the Case of Libya). Manchester, Manchester Metropoltan University.

Mathews, M. R. (1993). Socially responsible accounting. London: Chapman \& Hall.

McGuire, J., Dow, S., \& Argheyd, K. (2003). CEO incentives and corporate social performance. Journal of Business Ethics, 45, 341-359. http://dx.doi.org/10.1023/A:1024119604363

McWilliams, A., \& Siegel, D. (2001). Corporate social responsibility: A theory of the firm perspective. The Academy of Management Review, 26, 117-127. http://dx.doi.org/10.5465/AMR.2001.4011987

Meek, G. K., Roberts, C. B., \& Gray, S. J. (1995). Factors influencing voluntary annual report disclosures by US, UK and continental European multinational corporations. Journal of International Business Studies, 3, 555-572. http://dx.doi.org/10.1057/palgrave.jibs.8490186

Miles, M. B., \& Huberman, A. M. (1994). Qualitative data analysis: An expanded sourcebook. Claifornia: SAGE publications, Inc.

Moore, G. (2001). Corporate social and financial performance: an investigation in the UK supermarket industry. Journal of Business Ethics, 34, 299-315. http://dx.doi.org/10.1023/A:1012537016969

Murray, A., Sinclair, D., Power, D., \& Gray, R. (2006). Do financial markets care about social and environmental disclosure. Accounting, Auditing \& Accountability Journal, 19, 228-255. http://dx.doi.org/10.1108/09513570610656105

Naser, K., Al-Hussaini, A., Al-Kwari, D., \& Nuseibeh, R. (2006). Determinants of corporate social disclosure in developing countries: the case of Qatar. Advances in International Accounting, 19, 1-23. http://dx.doi.org/10.1016/S0897-3660(06)19001-7

Newson, M., \& Deegan, C. (2002). Global expectations and their association with corporate social disclosure practices in Australia, Singapore, and South Korea. International Journal of Accounting, 37, 183-213. http://dx.doi.org/10.1016/S0020-7063(02)00151-6

Noruésis, M. (1995). SPSS 6.1 guide to data analysis. Englewood Cliffs. NJ: Prentice Hall.

Parsa, S., \& Deng, L. X. (2008). Capital markets' reactions to social information announcements. International Journal of Accounting and Finance, 1, 107-120. http://dx.doi.org/10.1504/IJAF.2008.020239

Patten, D. (1991). Exposure, Legitimacy and Social Disclosure. Joumalof Accounting and Public Policy, 10, 297-308. http://dx.doi.org/10.1016/0278-4254(91)90003-3 
Patten, D. M. (2002). Give or Take on the Internet: An Examinationof the Disclosure Practices of Insurance Firm Web Innovators. Journal of Business Ethics, 36, 247-259. http://dx.doi.org/10.1023/A:1014009229437

Patton, M. Q. (1990). Qualitative evaluation and research methods. (2 ed.), California: Sage publishers.

Porter, M. E., \& Kramer, M. R. (2002). The competitive advantage of corporate philanthropy. Harvard Business Review, 80, 56-68.

Rettab, B., Brik, A. B., \& Mellahi, K. (2009). A study of management perceptions of the impact of corporate social responsibility on organisational performance in emerging economies: The case of Dubai. Journal of Business Ethics, 89, 371-390. http://dx.doi.org/10.1007/s10551-008-0005-9

Reverte, C. (2009). Determinants of corporate social responsibility disclosure ratings by Spanish listed firms. Journal of Business Ethics, 88(2), 351-366. http://dx.doi.org/10.1007/s10551-008-9968-9

Richardson, A. J., \& Welker, M. (2001). Social disclosure, financial disclosure and the cost of equity capital. Accounting, Organizations and Society, 26, 597-616. http://dx.doi.org/10.1016/S0361-3682(01)00025-3

Roberts, R. W. (1992). Determinants of corporate social responsibility disclosure: an application of stakeholder theory. Accounting, Organizations and Society, 17, 595-612. http://dx.doi.org/10.1016/0361-3682(92)90015-K

Sadeghzadeh, A. (1995). Social responsibility accounting, sustainability accounting and Islam. Ph.D. Dissertation, University of Wollongong, Sydney.

Silverman, D. (2004). Qualitative research: Theory, method and practice. London: Sage Publications Ltd.

Somekh, B., \& Lewin, C. (2005). Research methods in the social sciences. Thousand Oaks: Sage.

Trotman, K. (1979). Social responsibility disclosures by Australian companies. Chartered Accountant in Australia, 49, 24-28.

van der Laan Smith, J., Adhikari, A., \& Tondkar, R. H. (2005). Exploring differences in social disclosures internationally: A stakeholder perspective. Journal of Accounting and Public Policy, 24, 123-151. http://dx.doi.org/10.1016/j.jaccpubpol.2004.12.007

Waddock, S. A., \& Graves, S. B. (1997). The corporate social performance-financial performance link. Strategic $\begin{array}{llll}\text { Management Journal, } & 18, & 303-319 .\end{array}$ http://dx.doi.org/10.1002/(SICI)1097-0266(199704)18:4<303::AID-SMJ869>3.0.CO;2-G

Waller, D. S., \& Lanis, R. (2009). Corporate Social Responsibility (CSR) Disclosure of Advertising Agencies: An Exploratory Analysis of Six Holding Companies' Annual Reports. Journal of Advertising, 38, 109-122. http://dx.doi.org/10.2753/JOA0091-3367380107

Wanderley, L. S. O., Lucian, R., Farache, F., \& de Sousa Filho, J. M. (2008). CSR information disclosure on the web: a context-based approach analysing the influence of country of origin and industry sector. Journal of Business Ethics, 82, 369-378. http://dx.doi.org/10.1007/s10551-008-9892-z

WBCSD. (1998). World business council for sustainable development: Corporate social responsibility. Geneva: WBCSD publications.

Williams, M. (1999). Voluntary Environmental and Social Accounting Disclosure Practices in the Asia-Pacific Region: An International Empirical test of Political Economy Theory. The International Journal of Accounting, 34, 209-238. http://dx.doi.org/10.1016/S0020-7063(99)00006-0

Woodward, D. G., Edwards, P., \& Birkin, F. (1996). Organizational Legitimacy and Stakeholder Information Provision1. British Journal of Management, 7, 329-347. http://dx.doi.org/10.1111/j.1467-8551.1996.tb00123.x

Xianbing Liu, \& Anbumozhi, V. (2009). Determinant factors of corporate environmental information disclosure: an empirical study of Chinese listed companies. Journal of Cleaner Production, 17, 593-600. http://dx.doi.org/10.1016/j.jclepro.2008.10.001 
Appendix 1. Conceptual model of Factors Affecting of CSRD

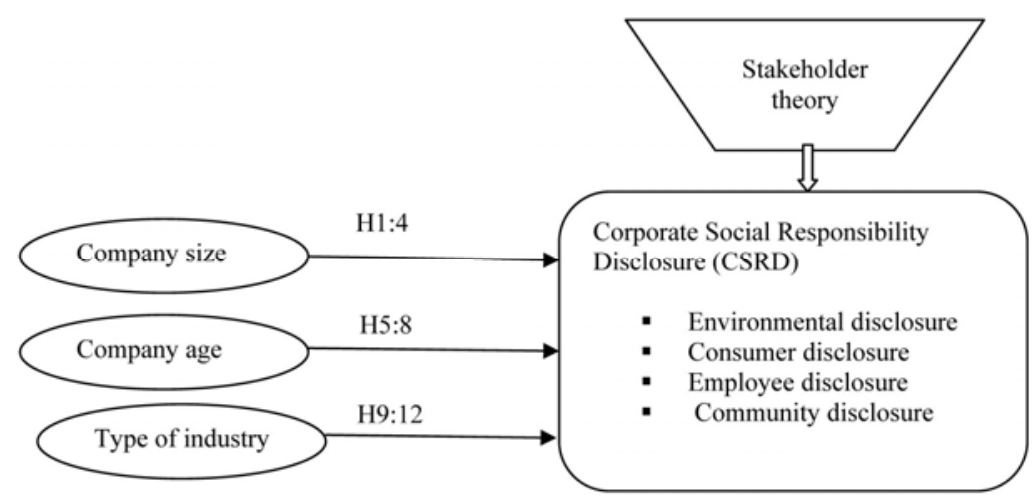

Appendix 2. Response Rate (content analysis)

\begin{tabular}{|l|c|c|c|c|c|}
\hline Sector & Manufacturing & Mining & Banking and Insurance & Services & Total \\
\hline Population (a) & 32 & 8 & 20 & 75 & 135 \\
\hline Final sample (b) & 12 & 1 & 13 & 14 & 40 \\
\hline Sample Rate (b/a) $\%$ & $37.5 \%$ & $12.5 \%$ & $65 \%$ & $19 \%$ & $30 \%$ \\
\hline
\end{tabular}

\section{Appendix 3. List of the Libyan Surveyed Business Enterprises}

\begin{tabular}{|l|l|l|l|}
\hline 1 & Al- Gafela Company & 21 & Water Company \\
\hline 2 & Inma Company for Buying Cars & 22 & Development Bank \\
\hline 3 & National Commercial Bank & 23 & Libya Insurance Company \\
\hline 4 & Trust Company for The Import and Process & 24 & The Agricultural Bank \\
\hline 5 & Sahara Company for Insurance & 25 & The national post \& Telecommunication Company \\
\hline 6 & Savings Bank and Real Estate Investment & 26 & Libyana Mobile Company \\
\hline 7 & National Company For Trade and Development & 27 & The Libyan Iron and Steel Company \\
\hline 8 & The General Electronic Company & 28 & AL-Jamhoria Bank \\
\hline 9 & Libya Telecom of Technology (LTT) & 29 & The Arabian Cement Company \\
\hline 10 & The Libyan Arab Foreign Bank & 30 & General National Maritime Transport Comp \\
\hline 11 & Al-Medar Communication Company & 31 & The Libyan Tractor Company \\
\hline 12 & Bank of Commerce and Development & 32 & Inma Company for Engineering Industries \\
\hline 13 & Al- Sahara Bank & 33 & Inma Company for Pipe Industries \\
\hline 14 & Sharara Company for Oil Services & 34 & National Company for Flour Mills and Foods \\
\hline 15 & Rahela Company for Oil Services & 35 & The General Tobacco Company \\
\hline 16 & National Company for Furniture Industries & 36 & The Libyan Truck and Bus Company \\
\hline 17 & Wehda Bank & 37 & The General Company for Chemical Industry \\
\hline 18 & United Bank For Commerce and Investment & 38 & Brega for oil selling \\
\hline 19 & The National Trailer Company & 39 & The National Electricity Company \\
\hline 20 & Serafa Company for Financial Services & 40 & Acacus Company For Oil Operating \\
\hline
\end{tabular}

\section{Appendix 4. Profiles of Interviewees}

\begin{tabular}{|l|c|c|c|}
\hline Sector Name & Financial Managers & Information Managers & Total \\
\hline Manufacturing & 8 & 4 & 12 \\
\hline Services & 11 & 1 & 12 \\
\hline Banks and Insurance & 4 & 2 & 6 \\
\hline Mining & 1 & 0 & 1 \\
\hline Total & 24 & 7 & 31 \\
\hline Participants rate & $77 \%$ & $23 \%$ & $100 \%$ \\
\hline
\end{tabular}




\section{Appendix 5. CSRD Areas}

\begin{tabular}{|c|c|c|}
\hline \multirow[t]{2}{*}{ Categories and subcategories of CSRD } & \multicolumn{2}{|c|}{ Annual Reports } \\
\hline & No & $\%$ \\
\hline - $\quad$ Environmental disclosure: & & \\
\hline 1- Environmental policy or company concern for the environment. & 32 & 29.09 \\
\hline 2- Environmental management, systems and Environmental audit. & 18 & 16.36 \\
\hline 3- Environmental-product and process. & 20 & 18.18 \\
\hline 4- Environmental financially. & 3 & 2.72 \\
\hline 5- Sustainability. & 4 & 3.63 \\
\hline 6- Energy. & 8 & 7.27 \\
\hline 7- Environmental other. & 26 & 23.36 \\
\hline - $\quad$ Consumer disclosure & & \\
\hline 1- Product and consumer safety & 82 & 74.54 \\
\hline 2- Consumer complaints & 23 & 20.90 \\
\hline 3- $\quad$ Prevision for disabled & 3 & 2.72 \\
\hline 4- $\quad$ Provision for difficult-to- reach customers. & 27 & 24.54 \\
\hline - Community involvement disclosure & & \\
\hline 1- Charity and political donations & 25 & 22.72 \\
\hline 2- $\quad$ Support for education. & 6 & 5.45 \\
\hline 3- Support for public health. & 3 & 2.72 \\
\hline 4- Support for the arts and culture. & 24 & 21.81 \\
\hline 5- $\quad$ Sponsoring sporting or recreational projects. & 18 & 16.36 \\
\hline - $\quad$ Employee disclosure & & \\
\hline 1- Employee data & 83 & 75.54 \\
\hline 2- $\quad$ Pension data & 35 & 31.81 \\
\hline 3- Consultation with employees & 7 & 6.36 \\
\hline 4- Employment of disabled & 3 & 2.72 \\
\hline 5- Value added statement & 3 & 2.72 \\
\hline 6- Health and safety & 47 & 42.72 \\
\hline 7- Share ownership & 5 & 4.54 \\
\hline 8- Equal opportunities & 3 & 2.72 \\
\hline 9- Employee other & 95 & 86.36 \\
\hline
\end{tabular}

\%: Disclosing companies as a percentage of total samples.

\section{Appendix 6. Descriptive Statistics for All Variables}

\begin{tabular}{|l|c|c|c|c|c|c|c|}
\hline Dependent Variables & Minimum & Maximum & Median & Mean & \multicolumn{1}{c|}{ Std. D } & Skewness & Kurtosis \\
\hline ENVD & 0 & 1 & 0.14 & 0.21675 & 0.256359 & 1.435 & 1.354 \\
\hline COND & 0 & 1 & 0.25 & 0.3825 & 0.2033533 & 0.804 & 1.153 \\
\hline COMD & 0 & 0.80 & 0.20 & 0.2550 & 0.2218223 & 0.843 & 0.197 \\
\hline EMPD & 0.11 & 0.56 & 0.33 & 0.35825 & 0.1174709 & $-0.477-$ & $-0.217-$ \\
\hline Independent Variables & \multicolumn{7}{|c|}{} \\
\hline Size & 5543094 & 17287053953 & 275901300 & 2191544745 & 4012904299 & 2.769 & 7.935 \\
\hline Age & 1 & 52 & 18 & 21.7 & 14.676 & 0.277 & $-1.112-$ \\
\hline Industry & 0 & 1 & 0 & 0.33 & 0.474 & 0.777 & $-1.473-$ \\
\hline
\end{tabular}

Note. This table presents descriptive statistics for all the variables of interest (environmental disclosure (ENVD), consumer disclosure (COND), community disclosure (COMD), employee commitment (EMPD), size, age and type of industry). 
Appendix 7. Pearson (above) and Spearman'S Rho (below) Correlation Coefficients between Company Characteristics and CSRD

\begin{tabular}{|c|c|c|c|c|c|c|}
\hline \multirow[t]{2}{*}{ Variables } & \multicolumn{2}{|c|}{ Size } & \multicolumn{2}{|c|}{ Age } & \multicolumn{2}{|c|}{ Type of Industry } \\
\hline & Correlation & Coefficients & Correlation & Coefficients & Correlation & Coefficients \\
\hline \multirow[t]{2}{*}{ ENVD } & $-0.199-$ & 0.230 & 0.120 & 0.460 & $0.519^{* *}$ & 0.001 \\
\hline & $-0.009-$ & 0.959 & 0.235 & 0.145 & $0.545^{* *}$ & 0.000 \\
\hline \multirow[t]{2}{*}{ COND } & 0.135 & 0.417 & $0.429^{* *}$ & 0.006 & $-0.059-$ & 0.717 \\
\hline & $0.392^{*}$ & 0.015 & $0.468^{* *}$ & 0.002 & $-0.073-$ & 0.656 \\
\hline \multirow[t]{2}{*}{ COMD } & 0.041 & 0.809 & 0.160 & 0.325 & 0.264 & 0.099 \\
\hline & 0.240 & 0.147 & 0.284 & 0.076 & 0.292 & 0.067 \\
\hline \multirow[t]{2}{*}{ EMPD } & $0.355^{*}$ & 0.029 & $0.443^{* *}$ & 0.004 & 0.190 & 0.240 \\
\hline & $0.439^{* *}$ & 0.006 & $0.465^{* *}$ & 0.003 & 0.209 & 0.196 \\
\hline \multirow[t]{2}{*}{ Size } & \multirow{2}{*}{\multicolumn{2}{|c|}{1}} & $0.548^{* *}$ & 0.000 & -0.310 & 0.058 \\
\hline & & & $0.601^{* *}$ & 0.000 & -0.279 & 0.090 \\
\hline \multirow[t]{2}{*}{ Age } & $0.548^{* *}$ & 0.000 & \multirow{2}{*}{\multicolumn{2}{|c|}{1}} & 0.056 & 0.733 \\
\hline & $0.601^{* *}$ & 0.000 & & & 0.042 & 0.799 \\
\hline \multirow[t]{2}{*}{ Type of Industry } & -0.310 & 0.058 & -0.056 & 0.733 & \multirow{2}{*}{\multicolumn{2}{|c|}{1}} \\
\hline & -0.279 & 0.090 & 0.042 & 0.799 & & \\
\hline
\end{tabular}

**. Correlation is significant at the 0.01 level (2-tailed). *. Correlation is significant at the 0.05 level (2-tailed).

Appendix 8. Model Summary

\begin{tabular}{|c|c|c|c|c|c|c|c|c|c|c|}
\hline \multirow[b]{2}{*}{ Model } & \multirow[b]{2}{*}{$\mathrm{R}$} & \multirow{2}{*}{$\begin{array}{c}\mathrm{R} \\
\text { Square }\end{array}$} & \multirow{2}{*}{$\begin{array}{l}\text { Adjusted R } \\
\text { Square }\end{array}$} & \multirow{2}{*}{$\begin{array}{l}\text { Std. Error of the } \\
\text { Estimate }\end{array}$} & \multicolumn{5}{|c|}{ Change Statistics } & \multirow[b]{2}{*}{ Durbin-Watson } \\
\hline & & & & & $\begin{array}{l}\text { R Square } \\
\text { Change }\end{array}$ & $\begin{array}{c}\mathrm{F} \\
\text { Change }\end{array}$ & df1 & $\mathrm{df} 2$ & $\begin{array}{l}\text { Sig. F } \\
\text { Change }\end{array}$ & \\
\hline 1 & 0.563 & .317 & .256 & .1969708 & .317 & 5.253 & 3 & 34 & .004 & 1.575 \\
\hline 2 & 0.477 & .227 & .159 & .1895650 & .227 & 3.336 & 3 & 34 & .031 & 1.183 \\
\hline 3 & 0.308 & .095 & .015 & .2218244 & .095 & 1.188 & 3 & 34 & .329 & 1.790 \\
\hline 4 & 0.516 & .266 & .201 & .1051482 & .266 & 4.112 & 3 & 34 & .014 & 1.537 \\
\hline
\end{tabular}

The independent variables are company size, company age and type of industry.

The dependent variable is Corporate Social Responsibility Disclosure (ENVD, model1; COSD, model2; COMD, model3 and EMPD, model4).

Appendix 9. ANOVA

\begin{tabular}{|c|l|r|r|r|r|c|}
\hline Model No: & Model details & Sum of Squares & df & Mean Square & F & Sig. \\
\hline 1 & Regression & 0.611 & 3 & 0.204 & 5.253 & 0.004 \\
& Residual & 1.319 & 34 & 0.039 & & \\
& Total & 1.931 & 37 & & & \\
\hline \multirow{2}{*}{2} & Regression & 0.360 & 3 & 0.120 & 3.336 & 0.031 \\
& Residual & 1.222 & 34 & 0.036 & & \\
& Total & 1.581 & 37 & & & \\
\hline \multirow{2}{*}{3} & Regression & 0.175 & 3 & 0.058 & 1.188 & 0.329 \\
& Residual & 1.673 & 34 & 0.049 & & \\
& Total & 1.848 & 37 & & & \\
\hline \multirow{2}{*}{4} & Regression & 0.136 & 3 & 0.045 & 4.112 & 0.014 \\
& Residual & 0.376 & 34 & 0.011 & & \\
& Total & 0.512 & 37 & & & \\
\hline
\end{tabular}

a. Predictors: (Constant), Company Size, Company Age and Industry Type.

b. Dependent Variable: Corporate Social Responsibility Disclosure (ENVD, model1; COSD, model2; COMD, model3 and EMPD, model4).

Notes: The table shows the ANOVA statistics for the regression models. The F statistic and the associated significance value show that the regression model explains a significant amount of the variation in the levels of CSRD. 


\section{Appendix 10. Coefficients}

\begin{tabular}{|c|c|c|c|c|c|c|c|c|}
\hline \multirow{2}{*}{ Model No: } & \multirow{2}{*}{ Model details } & \multicolumn{2}{|c|}{ Unstandardized Coefficients } & \multirow{2}{*}{$\begin{array}{c}\text { Standardized Coefficients } \\
\text { Beta } \\
\end{array}$} & \multirow{2}{*}{$\mathrm{t}$} & \multirow{2}{*}{ Sig. } & \multicolumn{2}{|c|}{ Collinearity Statistics } \\
\hline & & $\mathrm{B}$ & Std. Error & & & & Tolerance & VIF \\
\hline \multirow[t]{4}{*}{1} & Constant & .044 & .064 & & .688 & .496 & & \\
\hline & Company Size & .000 & .000 & -.263 & -1.466 & .152 & .623 & 1.606 \\
\hline & Company Age & .005 & .003 & .353 & 2.064 & .047 & .686 & 1.457 \\
\hline & Industry Type & .203 & .073 & .418 & 2.775 & .009 & .887 & 1.128 \\
\hline \multirow[t]{4}{*}{2} & Constant & .236 & .062 & & 3.341 & .001 & & \\
\hline & Company Size & .000 & .000 & -.182 & -.953 & .347 & .623 & 1.606 \\
\hline & Company Age & .008 & .003 & .552 & 3.031 & .005 & .686 & 1.457 \\
\hline & Industry Type & -.021 & .070 & -.049 & -.305 & .762 & .887 & 1.128 \\
\hline \multirow[t]{4}{*}{3} & Constant & .176 & .072 & & 2.440 & .020 & & \\
\hline & Company Size & .000 & .000 & .080 & .388 & .701 & .623 & 1.606 \\
\hline & Company Age & .001 & .003 & .097 & .491 & .627 & .686 & 1.457 \\
\hline & Industry Type & .142 & .082 & .298 & 1.722 & .094 & .887 & 1.128 \\
\hline \multirow[t]{4}{*}{4} & Constant & .268 & .034 & & 7.850 & .000 & & \\
\hline & Company Size & .000 & .000 & .267 & 1.436 & .160 & .623 & 1.606 \\
\hline & Company Age & .002 & .001 & .304 & 1.716 & .095 & .686 & 1.457 \\
\hline & Industry Type & .064 & .039 & .254 & 1.631 & .112 & .887 & 1.128 \\
\hline
\end{tabular}

Notes: This table reports the value of the coefficients for the variables and their significance. Although the relationship between some variables are insignificant, still the value of the coefficients is to some extent explains that the independent variable is associated with the dependent variable.

\section{Appendix 11. The Impact of Company and Industry Factors on CSR Information Disclosed}

\begin{tabular}{|c|c|c|}
\hline Factors & Number of interviews & The percentage of interviews \\
\hline Company size & 17 out of 31 & $55 \%$ \\
\hline Company age & 18 out of 31 & $58 \%$ \\
\hline Type of industry & 21 out of 31 & $68 \%$ \\
\hline
\end{tabular}

